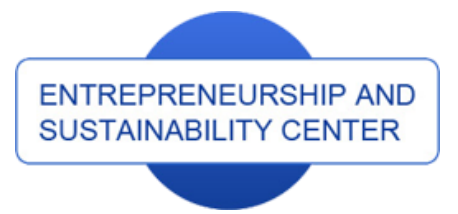

Publisher

http://jssidoi.org/esc/home enterprise

europe

network

Business Support on Your Doorstep

\title{
CASPA Scopus:
}

\section{THE BRAZILIAN AMAZON: A RESOURCE CURSE OR RENEWED COLONIALISM?*}

\author{
Martina Iorio' ${ }^{1}$, Salvatore Monni², Barbara Brollo ${ }^{3}$ \\ 1,2,3 Università degli Studi Roma Tre, Via Silvio D'Amico 77, Rome IT-00145, Italy \\ E-mails: ${ }^{1}$ martina.iorio@uniroma3.it; ${ }^{2}$ salvatore.monni@uniroma3.it; ${ }^{3}$ bar.brollo@ stud.uniroma3.it
}

Received 14 September 2017; accepted 15 January 2018; published 30 March 2018

\begin{abstract}
The aim of this paper is to highlight the effect of the endowment of resources on development through the analysis of the impact of national strategy, both at a regional and local level. The research focuses on the Legal Amazon ${ }^{\dagger}$, through the georeferenced analysis of socio-economic data from the last three censuses (1991, 2000 and 2010), in order to demonstrate how the Brazilian national energy strategy is contributing to the perpetuation of the phenomenon of the endowment trapt at a regional level. Despite boosting the national growth, the concentration of sector-based projects in resource-abundant areas is unable to eradicate inequalities, which in turn perpetuates the path dependences. $^{\S}$.
\end{abstract}

\footnotetext{
* This research was supported by the project AguaSociaL an FP7-PEOPLE-2013-IRSES - Marie Curie Action "International Research Staff Exchange Scheme", Grant Agreement Number 612633
}
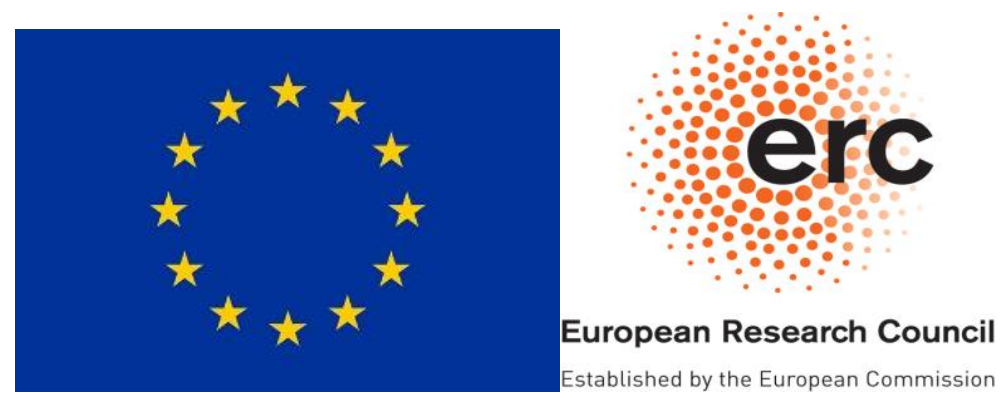

$\dagger$ Composed by all seven states of the Northern Region (Acre, Amapá, Amazonas, Pará, Rondônia, Roraima, Tocantins) to which the Maranhão (North-East Region) and the Mato Grosso (Center-East) are also added.

\$ Occurs when the development trajectory of a resource-abundant country mainly relies on primary product exploitation (Auty, 2001). The phenomenon can also produce the same implications in the internal energy market.

$\S$ The concept aims to frame the way in which historical events can 'lock in' pathways of development (Martin and Sunlay, 2006). 
The International Journal
ENTREPRENEURSHIP AND SUSTAINABILITY ISSUES

ISSN 2345-0282 (online) http://jssidoi.org/jesi/

2018 Volume 5 Number 3 (March)

http://doi.org/10.9770/jesi.2018.5.3(2)

Keywords: Brazil; Legal Amazon; Dependency; Inequality; Human Development

Reference to this paper should be made as follows: Iorio, M.; Monni, S.; Barbara Brollo, B. 2018. The Brazilian Amazon: a resource curse or renewed colonialism? Entrepreneurship and Sustainability Issues 5(3): 438-451. https://doi.org/10.9770/jesi.2018.5.3(2)

JEL Classifications: O38, O44, O54

\section{Introduction}

Following the recent Rousseff impeachment (OECD, 2015), Brazil is currently emerging from a political and economic crisis. Factors such as corruption as well as the social policies applied by President's Rousseff's party seem to have contributed to strengthened dependence at regional level rather than producing structural changes and improving welfare (Traspadini, 2014). As a consequence, political tools proposed by the current government are aimed at reducing public spending and stimulating growth, in line with the Latin American switch from heterodox economic policies to neoliberal interventions for a steady recovery (Wylde, 2016). Therefore, in order for economic growth to occur, energy production and its material applications (such as electrification) is of pivotal importance, even in spite of the threat this poses to territory and population (Kileber and Parente, 2015). Section two will outline the effect of the endowment of resources on the Brazilian energy strategy and highlight the role of Legal Amazon in the national energy strategy, taking into consideration the matter of misallocation of benefits from resource exploitation (Fearnside, 2016). Section three will then showcase a number of figures indicating how the realization of big projects have improved development in the state of Pará. Finally, section four will look at a brief study of the correlation between human development and income per capita (PNUD; IPEA; FJP 2017).

\section{A resource curse or renewed colonialism?}

Brazil is a medium income country with an abundance of natural resources (OECD, 2015). However, due to its developing condition, these characteristics expose it to the resource curse phenomenon (Costantini and Monni, 2008 a. and b.; Auty, 2001). Such dynamics may present themselves specifically in the scenario of the energetic sector (Kileber and Parente, 2015). However, regardless of its high hydroelectric potential, Brazil appears to have broken free of the energetic trap, despite the fact that the process of diversification does not follow the energy ladder $^{* *}$ criteria (Burke, 2012). In fact as the percentage of other renewable sources increases, the hydroelectric sector decreases only relatively, with a yet significant use of fossil fuel such as wood and coal, thus moving away from those objectives of environmental protection which truly represent a fundamental part of well-being (BrandCorrea and Steinberger, 2017).

A crucial topic relating to the exploitation of natural resources by a sector-based programme in Brazil is that of water destined for the use of energy production, since this allows Brazil to gain greater energy independence from the rest of the world. Though intended for noble purposes, this use of water generates notable impacts: firstly, institutions do not sufficiently facilitate an equitable and reliable supply of water; secondly, its pollution and uneven distribution affects social life and public health, since both private sectors and large public companies are more interested in focusing on the expected revenues from the energy sector rather than providing basic welfare

\footnotetext{
** The energy ladder concept posits that countries move to more sophisticated energy carriers as their income increases (i.e. shifting from traditional biomass to more modern and efficient fuels). For instance, in the energy sector high income conditions foster the development of new technologies of energy production which are usually cleaner and more modern than previous methods.
} 


\section{The International Journal}

ENTREPRENEURSHIP AND SUSTAINABILITY ISSUES

ISSN 2345-0282 (online) http://jssidoi.org/jesi/

2018 Volume 5 Number 3 (March)

http://doi.org/10.9770/jesi.2018.5.3(2)

services (Cori and Monni, 2015). Appropriation of water by public and private enterprises in order to produce energy may threaten the process of universalization of access to water. Furthermore, it can damage local economies (e.g. through the interruption of water flows that could have otherwise been used for transportation and commerce) with huge negative impacts being suffered mostly by the local communities (Monni and Realini, 2017).

The construction of extractive poles as a fully-fledged way to occupy the Amazon in the name of national interest has been implemented since the seventies; the area, as well as the reach of mineral resources and water, have suffered a thoughtless and accelerate occupation (Becker, 2005). National strategy has revealed itself to be of an excluding nature, rendering the development process extremely unbalanced and adverse for the Amazon. Sectorbased projects often benefit external actors (i.e. profit leakage and tax relief for foreign ventures), while the local population suffers environmental and social costs (Fernandes et al. 2017). Moreover, the exploitation and occupation of the land endanger the conservation and safeguarding of both the territory and its population and culture, making the matter of the Amazon a social and political issue rather than a merely technical-scientific one (Magalhães Filho, 1987; Fearnside, 2017).

\section{National programmes between economic growth and human development}

Since the era of the Grande Brasil ${ }^{\dagger \dagger}$ the Amazon has been subjected to sector-based programmes aimed at improving national development, as well as regional projects aimed at improving regional development, though the latter have proved unsuccessful in achieving the expected development goals (Magalhães, 1987). In fact, projects of regional interest usually absorb limited resources compared to national ones, which are instead highly financed by national and international capital. Nevertheless, although the latter strategies should ideally be conceived as inclusive, they tend to imply a small number of local concerns (Buarque, 1987). For example, whilst the northern region (which has been affected since the ' 70 s by sector-based programs due to its availability of resources) maintains unsatisfactory levels of development, the state of Pará has the lowest MHDI of the whole area (PNUD-IPEA-FJP 2017), regardless of the fact that it hosts Belém. In fact, in 1991 none of its municipalities belonged to the top 10 cities of the State. However, from 1991 to 2010, 3 of its municipalities remained among the last 10, with Melaço performing the worst MHDI (0.418) in 2010, not only out of the northern region but of Brazil as a whole (PNUD-IPEA-FJP, 2017).

Despite the realization of Grande Carajás, one of the main sector-based Brazilian programs, the state of Pará maintains unsatisfactory levels of development (PNUD; IPEA; FJP 2017). Our goal is to focus on this state in order to highlight the performance of 27 municipalities directly or indirectly affected by sector-based projects. The analysis is based on georeferentiated data (Lelo, 2011) from the last IBGE census $(1991,2000$ and 2010) and takes three indicators into account: the income per capita, the percentage of population vulnerable to poverty and the inequality (Sen, 2005; Ehrhart, 2009; Azeem et al., 2017; Santos et al., 2017; Menshikov et al., 2017). The selected municipalities are gathered into five groups depending on their geographical relation to their pertaining sector-based projects: M1 (upstream municipalities affected by Tucurí UHE); M2 (downstream municipalities affected by Tucuruí UHE); M2* (Barcarena, headquarter of Hydro Alunorte); M3 (municipalities affected by Belo Monte UHE); M4 (Santarem, headquarter of Silvio Braga UHE) (Map 1).

\footnotetext{
$\dagger \dagger$ Expression meaning "Big Brazil". It refers to the 5th Republic, that is to say the period of the dictatorship (Motta, 2007).

$\$$ Brazilian Institute of Geography and Statistics.
} 
Map 1. 27 municipalities affected by sector-based projects in Pará

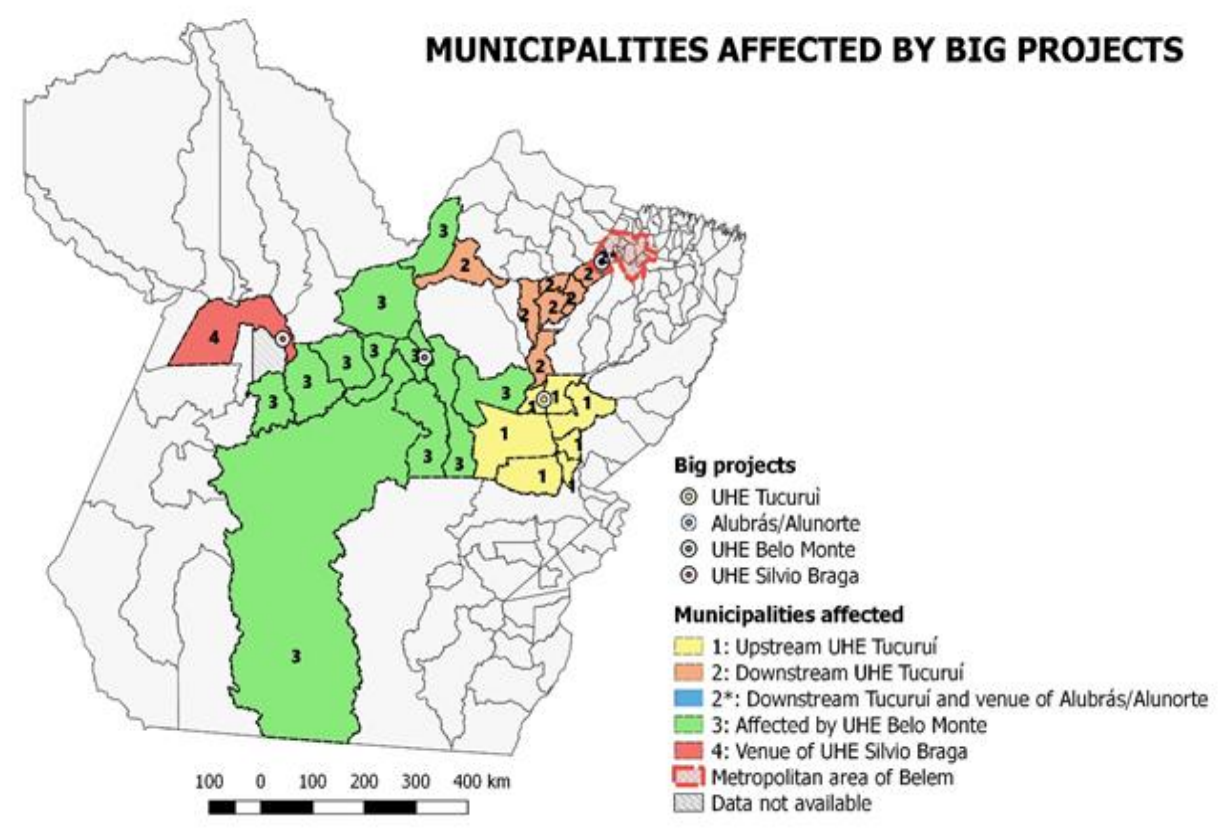

Source: Personal elaboration from PNUD; IPEA; FJP 2017

The more recent the year, the higher the income per capita in all groups. However, the data shows better results in terms of income increase than in terms of decrease of vulnerability to poverty. In fact, since the Gini index is the only ratio in which all target groups have performed increasingly worse throughout the years, in each year the substantial increase in income occurs in the presence of constant inequality (PNUD-IPEA-FJP, 2017).

The rate of growth of the income per capita is on average positive for all the units between 1991 and 2000. Brazil demonstrates a $+3 \%$ growth rate per year, as well as Pará and M4 with only M3 and M2 performing better (at $+5 \%$ and $+4 \%$ respectively). The worse performance is by M2* and M1 (+2\%). In the 2000-2010 decade, Brazil maintains a 3\% growth rate of income per capita, whilst lower growth rates occur in Pará for municipalities with a more advanced state of economic development (Map 2). 


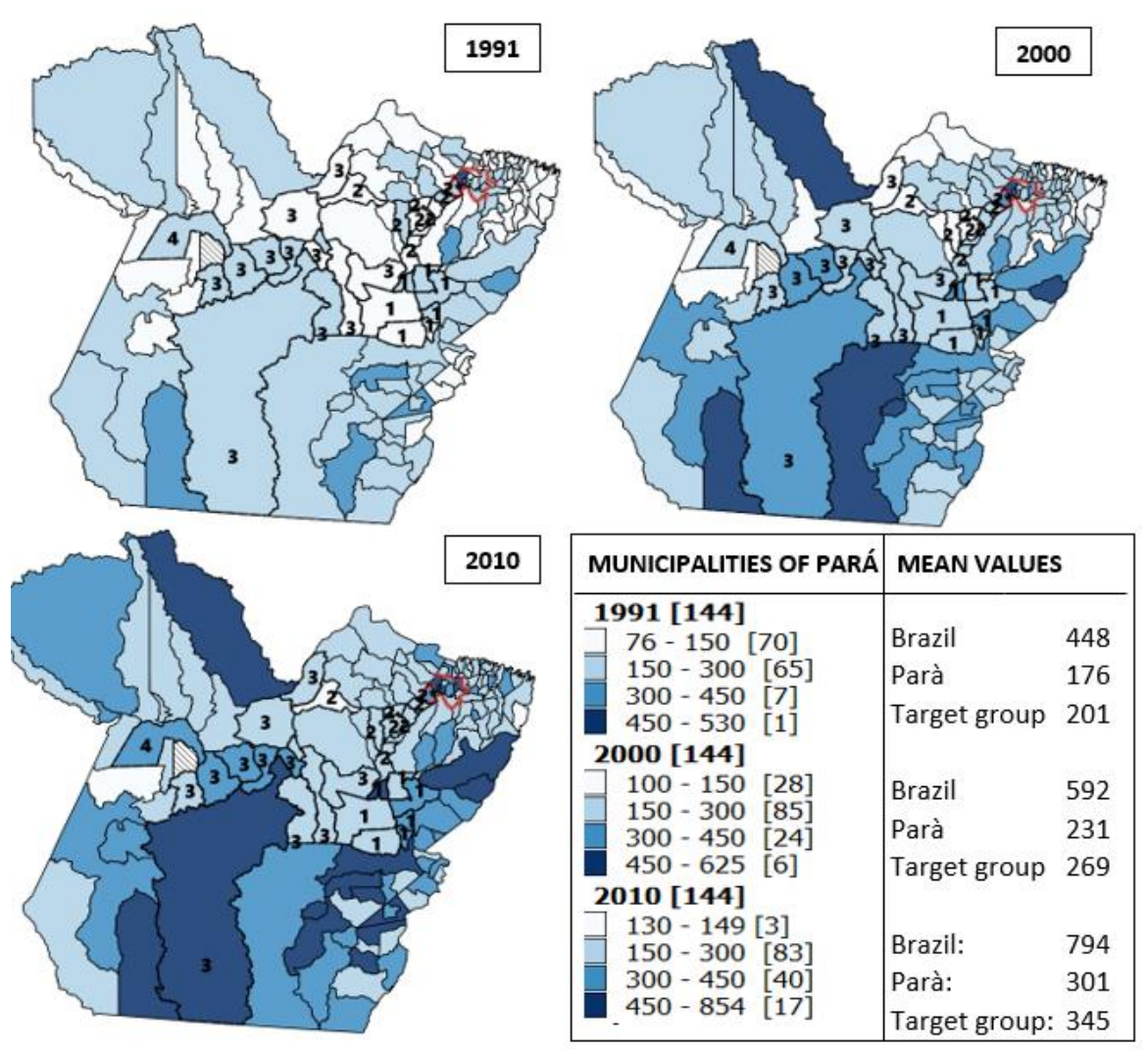

Source: Personal elaboration from PNUD-IPEA-FJP, 2017. Data relates to the ratio between the sum of the income of all individuals living in permanent private households and the total number of these individuals. Amounts in BR R\$ as of August $1^{\text {st }} 2010$.

However, though it is not possible to identify a trend owing to the lack of data (census data only) and to the fact that the behavior of the selected cities is largely heterogeneous, it can be said that from 1991 to 2010, each city has witnessed a reduction of sorts in the percentage of population vulnerable to poverty (Map 3). 


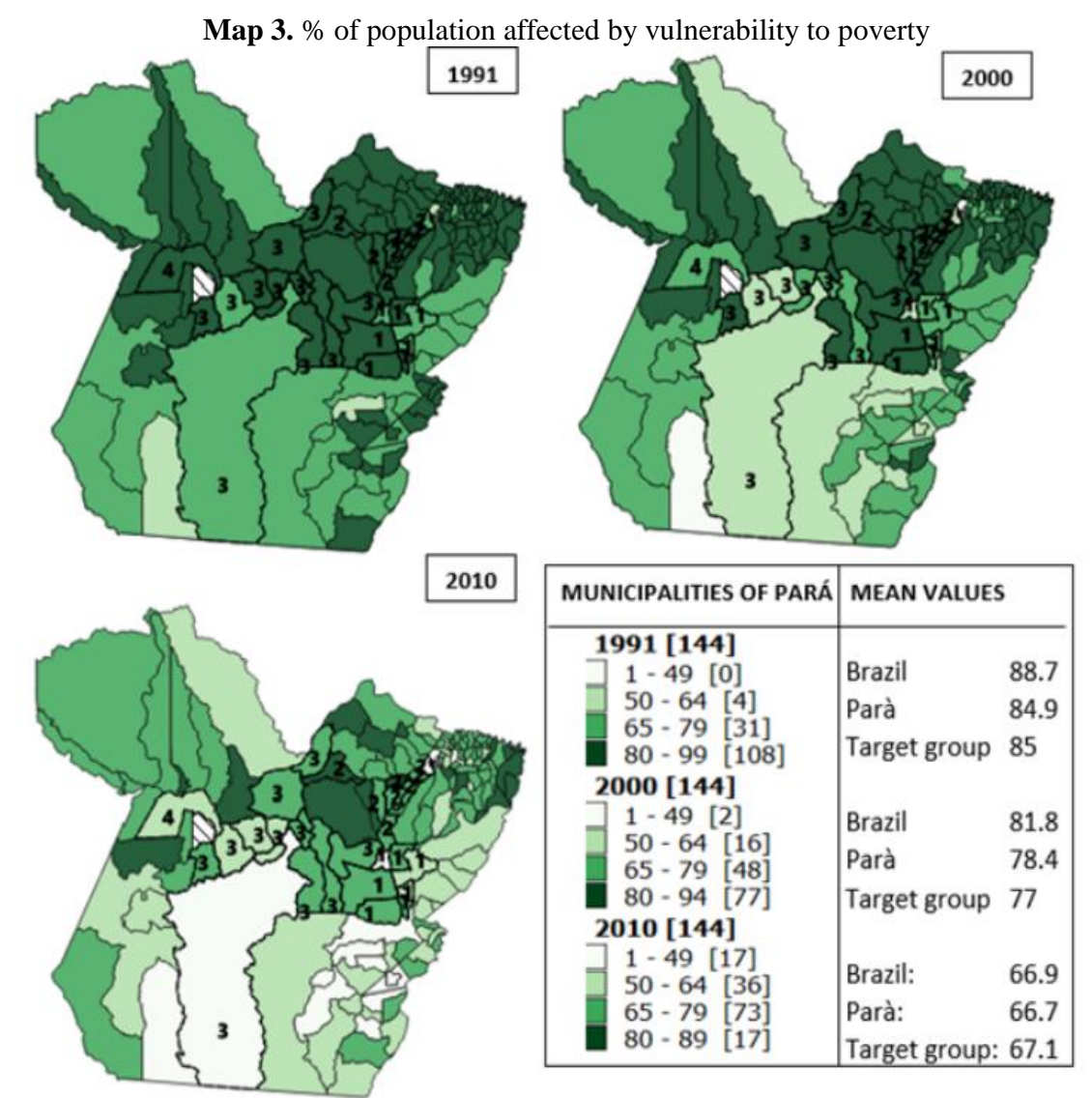

Source: Personal elaboration from PNUD-IPEA-FJP, 2017. Data refers to the proportion of individuals living in permanent private households with per capita household income equal to or less than 255 BR R \$ per month as of August $1^{\text {st }} 2010$, equivalent to $1 / 2$ minimum salary at that time

In 1991 high levels of vulnerability to poverty were registered at all levels of disaggregation, but a reasonable reduction is registered in 2000, with a further effort made in 2010. The best result has been achieved at a federal level: between 2000 and 2010 Brazil has reduced its vulnerability rate by $15 \%$. The decrease in poverty is not a sufficient indication of a positive trajectory of development since the Gini index holds disappointing results. For Tucuruí (the leading municipality in M2) and Altamira (the leading municipality in M3), both decades show that the change in population vulnerable to poverty ( $-41 \%$ and $-35 \%$ respectively) is less than proportional to the increase in per capita income $(+78 \%$ and $+107 \%$ ) (PNUD, 2017). Instead, the reduction in the percentage of the poverty-vulnerable population in $\mathrm{M} 2 *$ by $-78 \%$ is more proportional than the $+51 \%$ increase in per capita income throughout the whole period. In 2010 Santarem (M4) registered a vulnerability rate of 55\%, that is to say more than 10 points below the mean of Brazil, Pará and target municipalities $(66.9 \%, 66.7 \%$ and $67.1 \%$ respectively) 
The International Journal

ENTREPRENEURSHIP AND SUSTAINABILITY ISSUES

ISSN 2345-0282 (online) http://jssidoi.org/jesi/

2018 Volume 5 Number 3 (March)

http://doi.org/10.9770/jesi.2018.5.3(2)

(PNUD-IPEA-FJP, 2017). From decade to decade, all the selected municipalities show better results in terms of income increase than in terms of reduction of vulnerability to poverty (PNUD-IPEA-FJP, 2017) (Figire 1).

Fig. 1 Vulnerability to poverty
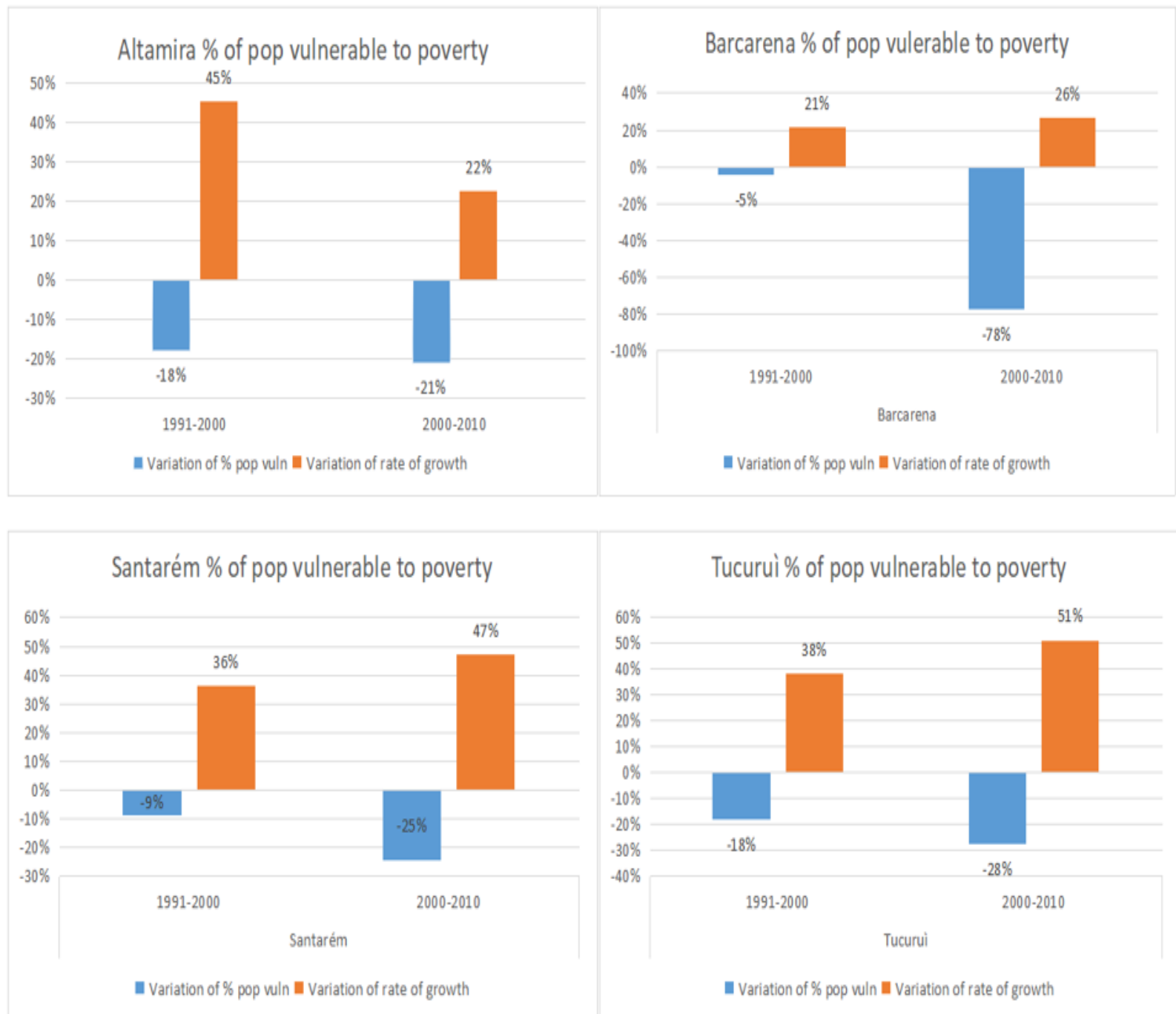

Source: Personal elaboration from PNUD-IPEA-FJP, 2017. The graph compares the variation of the rate of growth of the income per capita with the decrease of the percentage of population vulnerable to poverty in four pivotal cities in the state of Pará between 1991 and 2000 , and also between 2000 and 2010

At each level, the substantial increase in income occurs in the presence of constant inequality. The increase in inequalities is structured in two phases: the former, between 1991 and 2000, experienced an absolute worsening; the latter, between 2000 and 2010, showed a relative decreasing. In 2010, compared to 1991, Brazil had a worse income distribution, as can be seen by the +0.08 points increase in the Gini index, while both Pará and the target municipalities show a smaller increase in inequality, amounting to +0.03 points on average (Map 4). 
Map 4. Inequality (Gini Index)

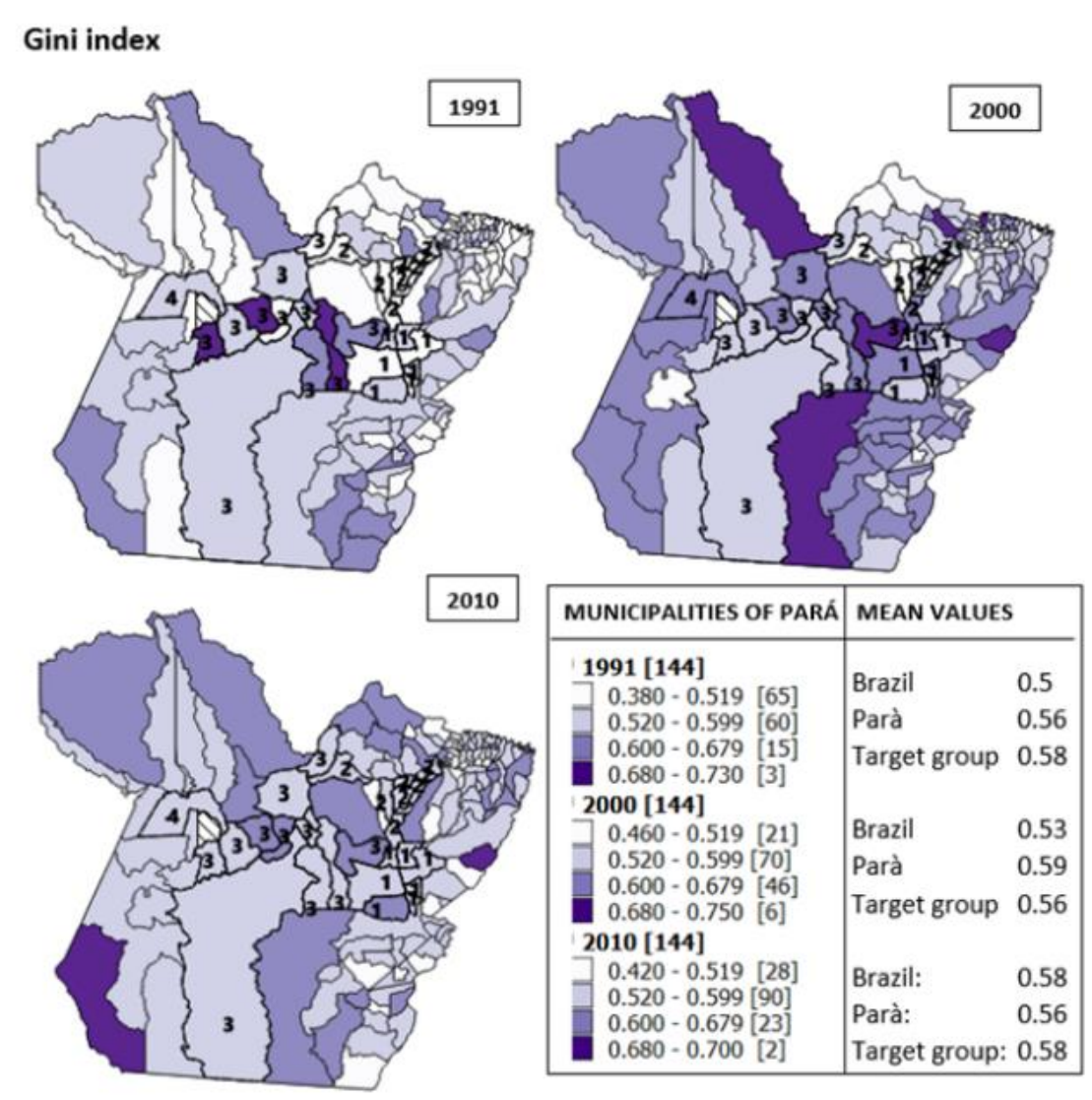

Source: Personal elaboration from PNUD-IPEA-FJP, 2017. Data measures the degree of inequality in the distribution of individuals according to per capita household income. Its value varies from zero when there is no inequality (household income per capita of all individuals has the same value) to 1 , when inequality is at its maximum (only one individuals owns all income). The population of individuals is limited to those living in permanent private households

All target groups obtained worse results when compared to Brazil and Pará. On the one hand, M2* (Barcarena, leading municipality of the M1 group) registered the highest value in 1991 and also in 2010, while M1's results are particularly worrying due to their constant increase in the index. Instead, in this scenario Tucuruí (the leading municipality of M2) has no change in the Gini index despite the increase in incomes (this would also partially explain the slow reduction of vulnerability to poverty). Tucuruí is reduces the percentage of vulnerability to poverty at a slower rate than the increase in per capita income. Moreover, despite its large power plant and energy attractiveness, the city scores a "potentially unsustainable" Gini index with a merely "intermediate" per capita income (Fapespa, 2016). On the other hand, although it was not yet hosting the Belo monte power plant, Altamira (the leading municipality of the M3 group) reduced inequality by $-2 \%$ and $-3 \%$, in the first and second decade respectively, recording a potentially unsustainable Gini index all the same (Fapespa, 2016). (Figure 2). 
Fig. 2. Gini Index

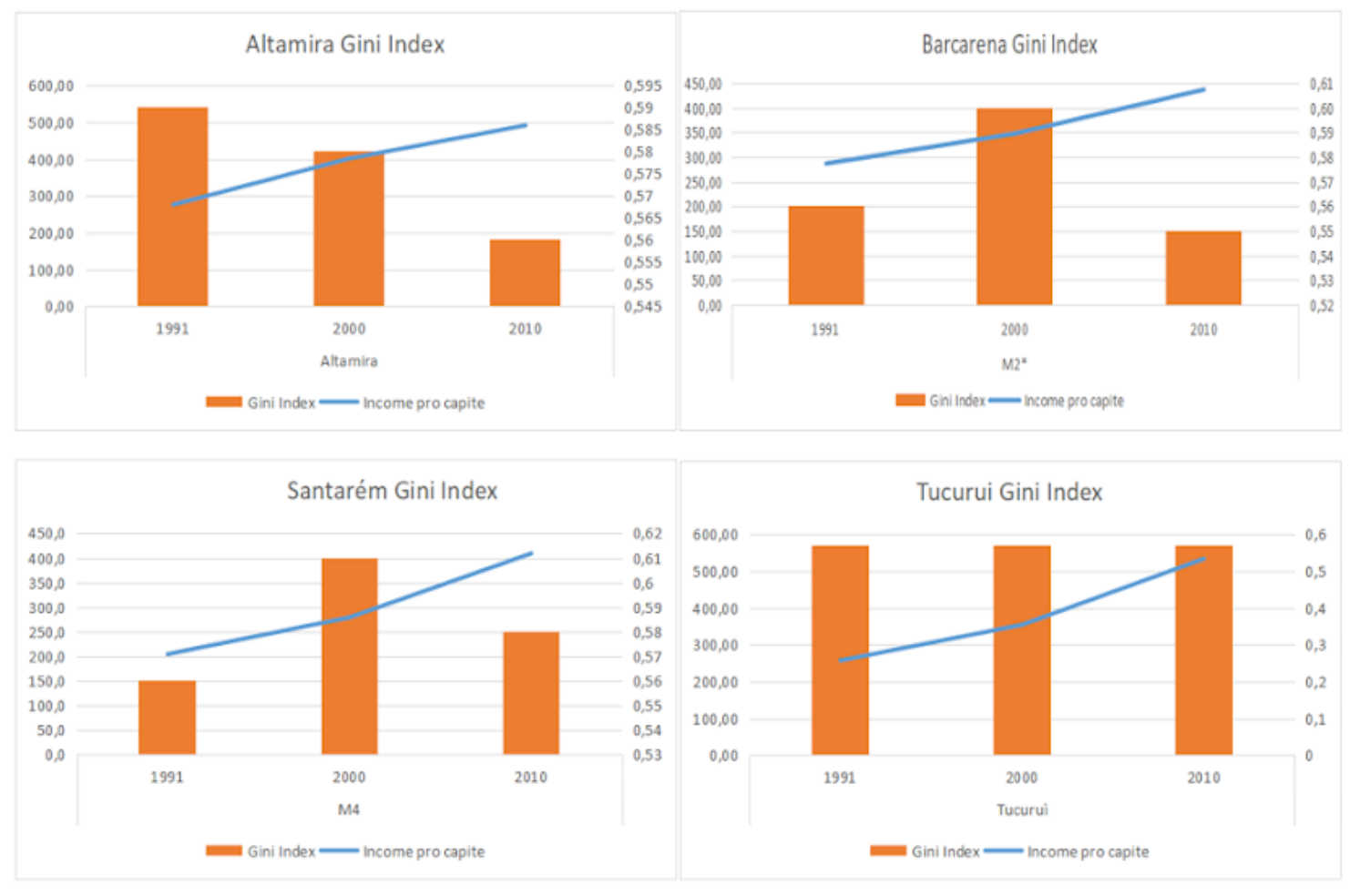

Source: Personal elaboration from PNUD-IPEA-FJP, 2017. The graph compares the income per capita (expressed in BR R $\$$ as of August $1^{\text {st }}$ 2010) with the Gini index for four pivotal cities in the state of Pará in 1991, 2000 and 2010

Such results are clearly also induced by the geo-political history of the territories in question.

Despite their common development path, the four main cities focused on in the above analysis display heterogeneous territories as well as heterogeneous inclinations (Rocha, 2008; 2016). However, it is important to acknowledge that at the time of analysis each city was affected by large heterogeneous sector-based projects (CBDB, 2011; Fapespa, 2015) which are still in act.

\section{The path of development}

Based on a logical dependence between per capita income and human development, it can be hypothesised that per capita income substantially induces changes in the human development index at a municipal level. In this case it can be defined as "logical" because the calculation of the MHDI is based on education, health and income.

For this reason, our focus was not to discover a scientific rule but to concentrate on the level of association between the income per capita and the human development (measured as Municipal Human Development Index, MHDI) throughout the Spearman's correlation index $\rho$ (rho), namely a co-graduation index applied on ordered 
The International Journal

ENTREPRENEURSHIP AND SUSTAINABILITY ISSUES

ISSN 2345-0282 (online) http://jssidoi.org/jesi/

2018 Volume 5 Number 3 (March)

http://doi.org/10.9770/jesi.2018.5.3(2)

values $^{\S \S}$ in order to recognise the extent to which the income per capita has a role in explaining the MHDI ${ }^{* * *}$ (Hauke, Kossowsky, 2011). The graph clearly indicates that even when very low, the association is always positive $(0<\rho<1)$. This positive correlation increases each year for every group. M1 shows the lowest association, while M2 and M3 show a highly positive correlation (already in 1991), presenting similar variations throughout the years. The association mentioned above decreases if we are to consider the total sample $(n=27)$. (Figure 3).

Fig. 3. Spearman's co-graduation index $\rho$ (rho)

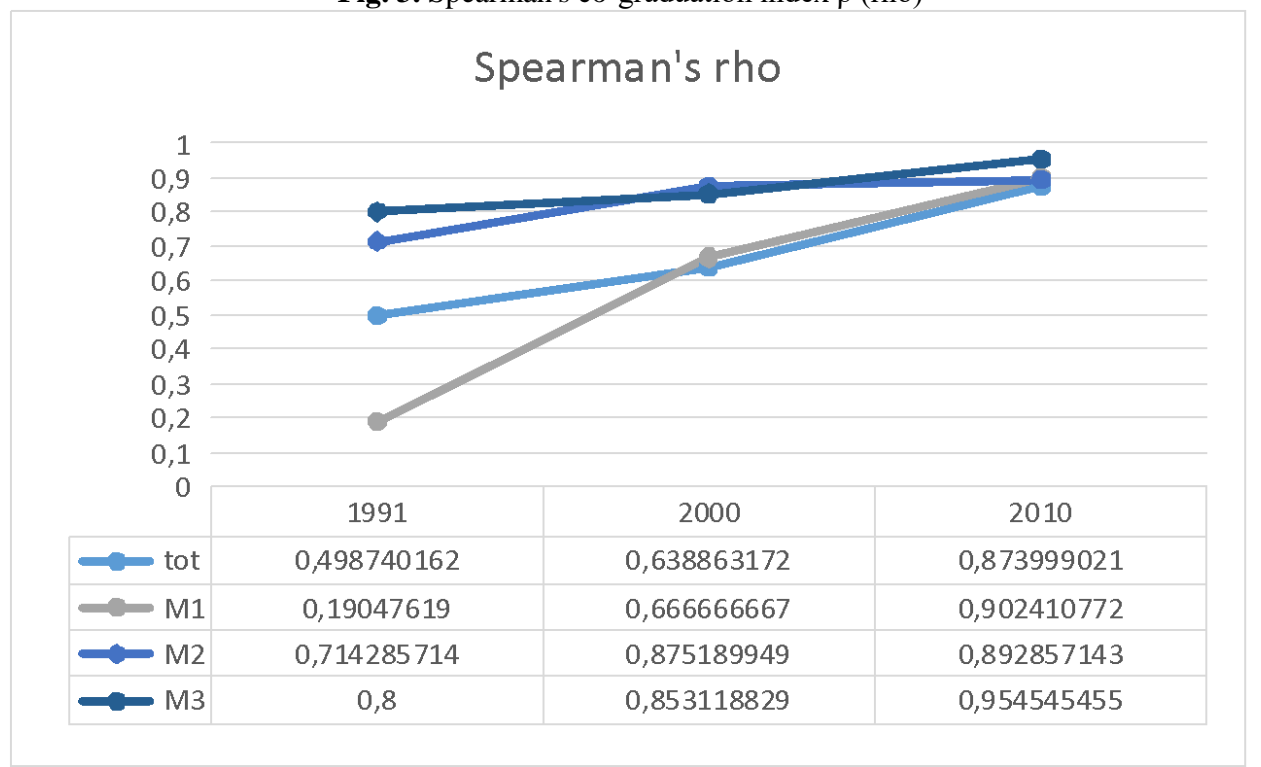

Source: Personal elaboration from PNUD-IPEA-FJP, 2017

It can be concluded that the index of co-graduation in 2010 is high and almost homogeneous for all subgroups, with $\rho>0.80$ in all cases. This indicates that the role of per capita income, though not the only determinant of development, is gaining an increasingly decisive role. However, its role remains the smallest in the area with the worst distribution of income (M1) which is in turn the most exposed to the negative effects of the national intervention in the exploitation of local natural resources (i.e. downstream effect of the Tucuruí hydroelectric plant).

\section{Conclusions}

A trade-off between national growth and human development clearly exists and is particularly severe for emerging countries which are also perceived to hold the greatest pollutant potential and the highest likelihood to shift from a dirty to clean development paradigm. Renewable energies increase as they become progressively considered as the best solution for combining development achievements whilst preserving ecosystem services.

$\S \S$ We must first order the values of all municipalities on a scale from 1 to $27(\mathrm{n}=27)$ in order to calculate the total Spearman's index. We then re-calculate the rankings within each group, on the basis of different scales (i.e. $\mathrm{n}=8$ for $\mathrm{M} 1$, $\mathrm{n}=7$ for M2 and n=11 for M3), to calculate the target group's Spearman indexes (Total Spearman index does not change).

${ }^{* * *}$ That is to say how much the error in predicting the rank of a municipality with regards to MHDI can be reduced if we take into account the rank of the same unit with regards to income per capita. The index has a value between 1 and $-1: \rho=1$ the units have the same rank in both rankings; $\rho=0$ the two rankings have no association; $\rho=-1$ units never have the same rank in both rankings. 
The International Journal

ENTREPRENEURSHIP AND SUSTAINABILITY ISSUES

ISSN 2345-0282 (online) http://jssidoi.org/jesi/

2018 Volume 5 Number 3 (March)

http://doi.org/10.9770/jesi.2018.5.3(2)

However in Brazil's case, though the Amazon has a great mining and hydroelectric potential and as is generally the case with natural resources, the uneven distribution of benefits and costs from its exploitation affects the energy strategy and the development of the region. In fact, the return on investment represents a true measure of a project's contribution to social welfare only if it is evaluated at its social-environmental opportunity cost (Costantini et al., 2016).

Therefore, the overall evaluation of the indicators mentioned above outlines the real holistic progress made in local contexts in Brazil, especially in cases of implementation of sector-based national programmes. This is an important starting point when dealing with the implementation of new strategies: if lessons are successfully learned from past experiences, the evaluation of future development proposals can be greatly improved to allow for policy makers to be better informed in their investment decisions.

The Gini index is the only indicator in which target groups register worse results than both the country and the state. This is highly indicative of the development model of sector-based projects: though they assure a great influx of capitals, the lack of adequate structural policies means that they merely contribute to national economic growth whilst overlooking the human development in affected areas (Caravaggio and Iorio, 2015).

We therefore propose to provide knowledge in order to aid the reviewing of the country's development agenda. Alongside the integrated process of national growth and throughout the combined struggle against poverty and inequality as instruments for a balanced development, we propose a medium-to-long term objective of overcoming the Amazon's current categorisation as "Brazil's backyard" (Pinto, 2017) in favor of a dual development strategy based on the exploitation-conservation of resources and territory, so as to ensure a sustainable national growth and regional integration (Magalhaes, 1987).

\section{References}

Auty, R.M. 2001. The political economy of resource-driven growth, European Economic Review 45, 839-846. https://EconPapers.repec.org/RePEc:eee:eecrev:v:45:y:2001:i:4-6:p:839-846

Azeem M. M.; Mugera A.W.; Schilizzi S. 2017. Vulnerability to Multi-Dimensional Poverty: an empirical comparison of alternative measurement approaches, The Journal of Development Studies, 1-25. DOI: https://doi.org/10.1080/00220388.2017.134464

Becker B.K. 2005. Geopolítica da Amazônia, Estudos Avançados 19 (53), 71-86. http://dx.doi.org/10.1590/S0103-40142005000100005

Brand-Correa L.I.; Steinberger J.K. 2017. A framework for decoupling human need satisfaction from energy use, Ecological Economics 141, 43-52. https://doi.org/10.1016/j.ecolecon.2017.05.019

Buarque, C. 1987. Notas para uma metodologia de avaliação aos grandes projetos da Amazônia, in Costa J.M.M. da (coord.), Os grandes projetos da Amazônia: Impactos e Perspectivas, Belém: Cadernos NAEA 9, 104-127.

Burke, P.J. 2010. Income, resources, and electricity mix, Energy Economics 32, 616-626. https://doi.org/10.1016/j.eneco.2010.01.012 
The International Journal

ENTREPRENEURSHIP AND SUSTAINABILITY ISSUES

ISSN 2345-0282 (online) http://jssidoi.org/jesi/

2018 Volume 5 Number 3 (March)

http://doi.org/10.9770/jesi.2018.5.3(2)

Caravaggio, N; Costantini, V.; Iorio, M.; Monni, S.; Paglialunga, E. 2016. The challenge of hydropower as a sustainable development alternative. Benefits and controversial effects in the case of the Brazilian Amazon, in Fadda, S. and Tridico, P. (Ed.). Inequality and Uneven Development in the Post-Crisis World. Oxon, OX: Routledge, 213-237.

Caravaggio, N.; Iorio, M. 2016. Management of water resources in the Amazon region. 2015 Conference on International Sustainable Ecological Engineering Design for Society (SEEDS): Paper prepared for presentation at the "SEEDS First International Conference". February 17th-18th Leeds, UK. Available on the Internet:

http://eprints.leedsbeckett.ac.uk/1845/1/SEEDS\%20Conference\%202015\%20-\%20Papers.pdf\#page=320

Comitê Brasileiro de Barragens (CBDB) 2011. A história das barragens no Brasil, Séculos XIX, XX e XXI, in Minguez, F.M. de (coord.) and Piasentin, C. (ed.). Cinquenta anos do Comitê Brasileiro de Barragens. Rio de Janeiro, Brasil.

Cori, A.; Monni, S. 2015. Neo-extractivism and the Resource Curse Hypothesis: Evidence from Ecuador, Development 58 (4): $594-607$.

Costantini, V.; Monni, S. 2008. Environment, Human Development and Economic Growth, in Ecological Economics 4: 867-880. http://www.sciencedirect.com/science/article/pii/S0921-8009(07)00328-X

Costantini, V.; Monni, S. 2008, Sustainability and Human Development, in Economia Politica - Journal of Analytical and Institutional Economics, 25 (1): 11-32. https://doi.org/10.1016/j.ecolecon.2007.05.011

Ehrhart C. 2009, The Effects of Inequality on Growth: A Survey of the Theoretical and Empirical Literature, ECINEQ Working Paper No. 107/09, Available on the Internet: http://www.ecineq.org/milano/WP/ECINEQ2009-107.pdf.

Fundação Amazônia de Amparo a Estudos e Pesquisas do Pará (FAPESPA) 2015, Barcarena: Estatística Municipal, Belém, BR. Available on the Internet: www.fapespa.pa.gov.br

Fundação Amazônia de Amparo a Estudos e Pesquisas do Pará (FAPESPA) 2016, Barômetro da Sustentabilidade da Amazônia /Diretoria de Estudos e Pesquisas Ambientais, Belém, BR. Available on the Internet:

http://www.fapespa.pa.gov.br/upload/Arquivo/anexo/1126.pdf?id=1520360627

Fearnside, P.M. 2016, Environmental policy in Brazilian Amazonia: lessons from recent history: a política ambiental na Amazônia brasileira: lições da história recente, Novos Cadernos NAEA 19 (1): 27-46. Available on the Internet: http://philip.inpa.gov.br/publ_livres/Preprints/2014/Fearnside-Lessons\%20of\%20history-Environ_Policy_Preprint.pdf

Fearnside, P.M. 2017, Hidrelétricas na Amazônia: Impactos ambientais e sociais na tomada de decisões sobre grandes obras. Preparatório da Engenharia e Agronomia para $8^{\circ}$ Fórum Mundial da Água: Seminar prepared for presentation at Conselho Regional de Engenharia e Agronomia do Amazonas (CREA-AM), Tropical Hotel. May 11th Manaus, AM, Brazil. Available on the Internet: http://mundialagua.confea.org.br/wp-content/uploads/2017/03/Palestra-Philip-M.-Fearnside.pdf

Fernandes V.B.; Reydon B.P.; Passos D.S., Bueno A.P., 2017. Land governance, land policy and indigenous people. Land use and access rights in the Brazilian Amazon and Matopiba after the constitution of 1988. Annual World Bank conference on Land and Poverty: Paper prepared for presentation at the "2017 World Bank conference on Land and Poverty". March 20th-24th Washington DC, United States. Available on the Internet: http://governancadeterras.com.br/2017/wp-content/uploads/2017/10/Fernandes_819.pdf

Hauke, J; Kossowski, T 2011. Comparison of values of Pearson's and Spearman's correlation coefficients on the same sets of data, Quaestiones Geograficae 30 (2): 87-93. https://doi.org/10.2478/v10117-011-0021-1

Kileber S.; Parente V. 2015. Diversifying the Brazilian electricity mix: Income level, the endowment effect, and governance capacity, Renewable and Sustainable Energy Reviews 49: 1180-1189. http://www.sciencedirect.com/science/article/pii/S1364032115003792

Lelo K. 2011. Sistemi informativi geografici, in Munafo M. (ed.) "Rappresentare il territorio e l'ambiente”, Roma, Bonanno, $265-274$. 
The International Journal

ENTREPRENEURSHIP AND SUSTAINABILITY ISSUES

ISSN 2345-0282 (online) http://jssidoi.org/jesi/

2018 Volume 5 Number 3 (March)

http://doi.org/10.9770/jesi.2018.5.3(2)

Magalhães A.R. 1987. Impacto de grandes projetos na Amazônia, in Costa J.M.M. da (coord.), Os grandes projetos da Amazônia:

Impactos e Perspectivas, Belèm: Cadernos NAEA 9, 27-38.

Magalhães Filho F. 1987, Grandes projetos ou grande projeto?, in Costa J.M.M. da (coord.), Os grandes projetos da Amazônia: Impactos e Perspectivas, Belém: Cadernos NAEA 9,17-26.

Martin, R.; Sunlay, P 2006. Path Dependence and Regional Economic Evolution, Journal of economic geography, 6(4), $395-437$.

Menshikov, V.; Volkova, O.; Stukalo, N.; Simakhova, A. 2017. Social economy as a tool to ensure national security, Journal of Security and Sustainability Issues 7(2): 211-231. https://doi.org/10.9770/jssi.2017.7.2(4)

Monni, S.; Realini, A. 2017, AguaSociaL: Water as Freedom, Mimeo.

Motta, R.P.S.2007, A figura caricatural do gorila nos discursos da esquerda, ArtCultura 9 (15), 195-212..

OECD - Organization for Economic Co-operation and Development (2015), 2015 OECD economic survey of Brazil - Reigniting inclusive growth [available at: http://www.oecd.org/brazil/economic-survey-brazil.htm

Pinto, L.F. 2017, Internacionalizar para não internacionalizar a Amazônia. Projeto Descolonizar \#Amazonia: Seminar prepared for the presentation at Centro Cultural SESC Boulevard. June 27 $7^{\text {th }}$ 2017. Belém, PA, Brazil. Available on the Internet: https://descolonizar.tumblr.com/amazonia

PNUD; IPEA; FJP 2016, Desenvolvimento humano nas macrorregiões brasileiras, Brasilia: Published by PNUD Brasil.

PNUD-IPEA-FJP 2017, Atlas do desenvolvimento humano no Brasil, Available on internet: http://www.atlasbrasil.org.br/2013/pt/

Rocha, G.M.de 2008, Todos convergem para o lago! Hidrelétrica Tucuruí. Municipios e Territorios na Amazônia. Belém: Published by NUMA/UFPA.

Rocha, G.M.de 2016, Usina Hidrelétrica, dinâmica populacional e mudança espacial na região de integração Lago Tucuruí (1970-2010), in Rocha, G.M. de; Teisserec, P.; Sobrinho, M.V. (org.), Aprendizagem Territorial. Dinâmical Territoriais, Participação Social e Ação Local na Amazônia, Belém, Pará: NUMA, 77-102.

Santos M.E.; Dabus C.; Delbianco F. 2017, Growth and Poverty Revisited from a Multidimensional Perspective, The Journal of Development Studies, 1-18. DOI: https://doi.org/10.1080/00220388.2017.1393520.

Sen A. 2005. Human rights and capabilities, Journal of human development 6 (2), 151-166. https://doi.org/10.1080/14649880500120491

Traspadini, R. 2014, A Teoria da (inter)dependência de Fernando Henrique Cardoso. São Paulo: Published by OUTRAS EXPRESSÕES.

Wylde, C. 2016, The return of the right in Latin America, Institute of Latin American Studies - School of American Studies University of London: https://latinamericandiaries.blogs.sas.ac.uk/2016/11/16/the-return-of-the-right-in-latin-america 


\section{Aknowledgements}

*This research was supported by the project AguaSociaL an FP7-PEOPLE-2013-IRSES - Marie Curie Action "International Research Staff Exchange Scheme", Grant Agreement Number 612633
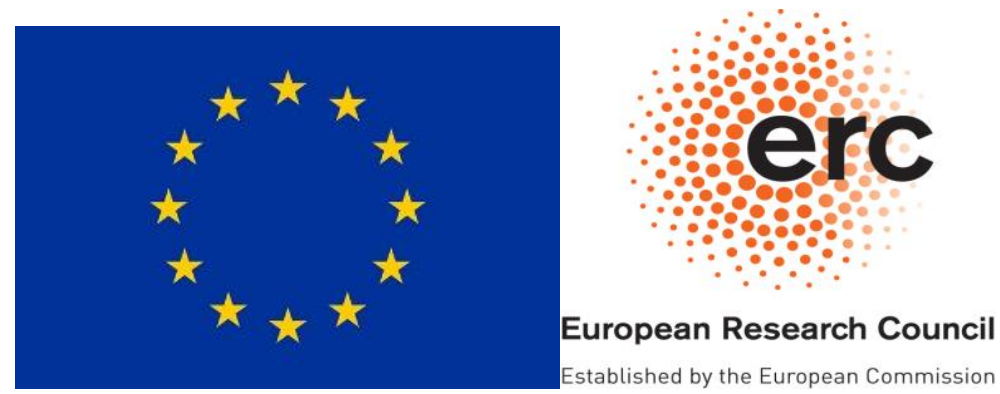

Martina IORIO is a Ph.D. student at Roma Tre University. Graduated from Federico II University of Naples, hold a Masters degree in Development Economics from Roma Tre University. Following a traineeship at Leeds Beckett University (U.K.) she participated in the AguaSociaL - Social Innovation in Brazil, in the Water Treatment Sector (an FP7 Marie Curie Action People Project). She has spent the past year studying as an exchange student and conducting research at the University of UFPA of Belém (PA) regarding development issues and water management.

ORCID ID: orcid.org/0000-0003-1686-3508

Salvatore MONNI is Associate Professor of Economic Policy and Director of the Master Program in "The Cooperative Firm: Economics, Law and Management", at Roma Tre University, Department of Economics. His current main research and publications are in the fields of development economics and policy. Salvatore is a graduate from "La Sapienza" (Rome, Italy), holds a Master of Arts in Development Economics from the University of Sussex (Brighton, UK) and a Ph.D. in Economics from Roma Tre University (Italy). He is Coordinator of SHUMED (Sustainable Human Development for MED Countries) and AguaSociaL (Social Innovation in Brazil, in the Water Treatment Sector), two FP7 Marie Curie Action People Projects and CLUSDEV MED (Cluster Development Med), an H2020 MSCA RISE project.

ORCID ID: orcid.org/0000-0002-6326-5714

Barbara BROLLO is researcher at CROMA, research center at Roma Tre University. Graduated in Development Economics at Roma Tre University, Economics Department. Research interests: urban studies, GIS, socio-economic inequalities, economic sociology.

ORCID ID: orcid.org/0000-0002-9909-8655

Register for an ORCID ID:

https://orcid.org/register

Copyright (C) 2018 by author(s) and VsI Entrepreneurship and Sustainability Center

This work is licensed under the Creative Commons Attribution International License (CC BY).

http://creativecommons.org/licenses/by/4.0/ 